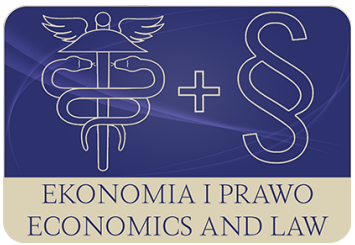

EKONOMIA I PRAWO. ECONOMICS AND LAW

Volume 19, Issue 3, September 2020

p-ISSN 1898-2255, e-ISSN 2392-1625

www.economicsandlaw.pl

EKONOMIA I PRAWO
ECONOMICS AND LAW

ORIGINAL ARTICLE

received 16.03.2020; revised 04.05.2020; accepted 30.09.2020

Citation: Chojnacka, E. (2020). One percent of personal income tax as a source of revenue in public benefit organisations. Ekonomia i Prawo. Economics and Law, 19(3): 449-465.

doi:10.12775/EiP.2020.030.

\title{
One percent of personal income tax as a source of revenue in public benefit organisations
}

\author{
EWA CHOJNACKA \\ Nicolaus Copernicus University in Torun, Faculty of Economic Sciences and Management, \\ Department of Financial Accounting, ul. Gagarina 13a, 87-100 Toruń, Poland \\ ๑ echoj@umk.pl \\ (D) orcid.org/0000-0002-7928-4725
}

\begin{abstract}
Motivation: Expert literature addresses the issue of funds transferred in the form of $1 \%$ of personal income tax for public benefit organisations (PBOs). Taking into consideration the fact that previous papers concentrated on the macro approach, a research gap has been observed regarding the analysis of the significance of the $1 \%$ mechanism as a source of revenue from the perspective of individual organisations.

Aim: The purpose of this paper is to assess the significance of $1 \%$ of personal income tax for thirty PBOs that receive the highest contributions from this source. This research aims to study whether the $1 \%$ mechanism is the main source of revenue for those PBOs and if the share of funds from $1 \%$ in total revenues was stable in subsequent years.

Results: The funds from $1 \%$ do not constitute the major source of total revenues for the $\mathrm{PBO}$ receiving the highest contributions under the $1 \%$ mechanism. The PBOs analysed in this paper differ in their structure of revenues and the share of funds from $1 \%$ of personal income tax in total revenues equals from $5 \%$ to $100 \%$ in the examined period. In eleven out of thirty PBOs the share of $1 \%$ income tax did not exceed $50 \%$ of total revenues in any of the years analysed. Only for three PBOs the difference between the maximum and the minimum share of funds from the $1 \%$ mechanism in total revenues was less than 5 percentage points in a given period.
\end{abstract}

Keywords: public benefit organisation; $1 \%$ of personal income tax; revenue structure JEL: L31; M41; Z23 


\section{Introduction}

Public benefit organisation (PBO) is a type of non-governmental entity which met special requirements and obtained the public benefit status. This concept was introduced into the Polish law in 2003 with the Act on public benefit activities and volunteering (2003). Research results demonstrate that most entities strive to gain the public benefit status because of the possibility of obtaining an additional source of revenue in the form of $1 \%$ of personal income tax (Ratajczak \& Chojecki, 2012, as cited in Kietlińska, 2015, p. 105). The introduction of the $1 \%$ mechanism was meant to strengthen social economy by providing financial support for public benefit activities offered by organisations from the third sector (Jegorow, 2017, p. 52; Piechota, 2015a, p. 12). The assessment of the $1 \%$ mechanism has been discussed in expert literature. Previous papers took into consideration several issues, such as:

- the analysis of the subsidy for non-profit organisations in terms of $1 \%$ of the tax due and the number of taxpayers who supported these organisations (Misiewicz, 2017; Musiałkiewicz, 2014; Piechota, 2015a);

- the evaluation of the $1 \%$ mechanism from the beneficiaries' point of view, indicating the strengths and weaknesses of the $1 \%$ mechanism (Kietlińska, 2015);

- the assessment of $1 \%$ allocations in territorial and purpose-related aspects (Piechota, 2015a);

- the motivations of Poles to support certain organisations and the cooperation of PBOs with local administrative bodies (Piechota, 2015a);

- the modifications of tax regulations and their impact on taxpayers' decisions (Misiewicz, 2016; 2017);

- the identification of trends and the optimum level of social involvement in terms of PBOs' revenues from $1 \%$ tax write-offs, the number of PBOs and the size of taxpayers' population deciding to transfer $1 \%$ of the tax due (Jegorow, 2017);

- the mechanism of competition on the $1 \%$ market on which PBOs conduct competitive struggle for the money which taxpayers can assign as well as the methods of this competitive struggle; the analysis was based on the statistics of the Ministry of Finance and on PBOs' reports (Czetwertyński, 2016). The research presented in the above-mentioned papers generally uses a macro approach. The $1 \%$ mechanism is more and more common and the number of taxpayers indicating a PBO in their tax return has been growing systematically. It turned out that it has become an important source of financing for certain entities, especially those which receive the highest contributions from $1 \%$ of personal income tax. Upon the consideration of previous research concerning the $1 \%$ mechanism, a research gap has been observed regarding the analysis of the significance of the $1 \%$ mechanism as a source of revenue from the perspective of individual organisations. To the best of the author's knowledge, earlier studies in this area include: 
- the presentation of ten PBOs that received the highest contributions from taxpayers assigning 1\% of their personal income tax in 2013 (Musiałkiewicz, 2014);

- the presentation of thirteen organisations that received the highest writeoffs from the $1 \%$ mechanism in 2009, 2011, and 2013 - in this study the absolute amounts of funds received from $1 \%$ were indicated with the position in the ranking of the Ministry of Finance, which comprises all PBOs obtaining contributions from 1\% of personal income tax (Kietlińska, 2015);

- the list of sixty-four PBOs which received above PLN 1 million under the 1\% mechanism in 2012, illustrating their standing in the ranking of the Ministry of Finance in 2010 and 2011 (Piechota, 2015a);

- the information about the first thirty PBOs in the ranking of the Ministry of Finance in 2015 with the amounts of contributions obtained by those entities (Czetwertyński, 2016).

In view of the above, the purpose of this paper is to assess the significance of the $1 \%$ of personal income tax write-off for the organisations with the public benefit status that receive the highest amounts owing to this solution. This research aims to demonstrate whether the $1 \%$ mechanism is the main source of revenue for those PBOs and if the share of funds from $1 \%$ in total revenues was stable in subsequent years. In order to achieve this purpose, expert literature and pertinent legal regulations have been analysed. Moreover, the information about the $1 \%$ personal income tax mechanism presented by Statistics Poland and the information from PBOs' annual reports have been gathered and evaluated. Thirty organisations, which obtained the highest amounts from $1 \%$ mechanism in 2018, were analysed with regard to the period 2011-2018.

The paper contains the introduction, a part concerning the legal regulations of the public benefit status in Poland, the methods used in the paper and the results of the analysis of $1 \%$ of personal income tax as a source of revenue for PBOs from a macro and micro- perspective. The conclusions summarise the considerations presented in the paper.

\section{The public benefit status in Poland as the basis of the $1 \%$ mechanism: a legal perspective}

According to the Polish law, the public benefit status may be gained by some non-governmental organisations and other legal entities indicated by law provided that they fulfil certain requirements. Non-governmental organisations are defined as corporate and non-corporate entities which are not a part of the public finance sector and do not operate for profit (Act on public benefit activities and volunteering, 2003, article 3.2). The most popular legal form of non-governmental organisations are foundations and associations, which are defined under separate provisions of Polish legislation, such as the Act on foundations (1984) and Act on associations (1989). In compliance with the Act on public benefit 
activities and volunteering (2003, art. 3.3 and 22.1), the other legal entities that may obtain the public benefit status include (NIW, 2020):

- legal persons and organisational units operating on the basis of the provisions on the relation of the State to the Catholic Church in the Republic of Poland, on the relationship between the State and other churches and religious associations, and on guarantees of freedom of conscience and religion if their statutory purposes include public benefit activities;

- joint stock companies, limited liability companies, and sports clubs being companies operating under the provisions of the Act on sport (2010), which do not work to achieve profit and allocate all of their income to the implementation of statutory objectives and do not allocate profit to be divided among their shareholders and employees.

The non-governmental organisations or other legal entities indicated above are entitled to obtain the public benefit status if they perform a public benefit activity. The Polish law indicates 39 areas of public activity which generally may be understood as the operations focused on benefiting the society in the area of public tasks (e.g. social assistance, health protection, ecology, animal protection) (Act on public benefit activities and volunteering, 2003, art. 3.1 and 4.1).

Non-governmental organisations or other legal entities are entitled to apply for the public benefit status after two years of operating in the field of public benefit activity. When the entity obtains the public benefit status, this fact should be confirmed with an appropriate entry into the National Court Register (Żak, 2012). The legislation on public benefit and volunteer work indicates additional requirements which have to be met by PBOs (Act on public benefit activities and volunteering, 2003, art. 20.1; NIW, 2020):

- they perform public benefit activities (defined in art. 4 of the Act on public benefit activities and volunteering (2003)) and this activity must include work to the benefit of the general community or a specific group provided that the group is separated due to particularly difficult circumstances or material situation in relation to society;

- they may run a business activity but only as an additional activity in relation to the public benefit activities;

- the surplus revenue remaining after the costs are covered (the income of the organisation) must be allocated to the public benefit activity;

- they must have a statutory collegiate supervisory and inspection body, separate from the management body and not subject to its internal control or supervision;

- the members of the supervisory and inspection body may not be members of the management body or be married to them, in cohabitation, in a relation of kinship, affinity or official subordination;

- the members of the supervisory and inspection body may receive, for the performance of their functions in such a body, reimbursement of reasonable costs or remuneration in an amount not higher than the average 
monthly remuneration in the enterprise sector announced by the President of Statistics Poland for the previous year;

- the members of the supervisory and inspection body or the management board must not be convicted with a legally enforceable verdict for an intentional offence punishable by public prosecution or for a fiscal offence;

- they must have their own statute (or other internal regulations) including required restrictions concerning loans, the use of the organisation's property and the purchases from entities connected with the members of the organisation.

Upon obtaining the public benefit status, organisations gain also certain benefits, the most important of which includes the right to receive funds from $1 \%$ of personal income tax. This source of revenue may be used only to finance public benefit activity. By introducing the $1 \%$ mechanism, the Polish legislator relied on solutions from Hungary (introduced in 1997) and Slovakia (introduced in 2002) (Jegorow, 2017, p. 50). Similar mechanisms, which enable supporting organisations with $1 \%$ of tax due were also introduced in Lithuania and Romania (Misiewicz, 2016, p. 292).

Initially, in compliance with the Polish law that was binding in the years 2004-2007, the group of taxpayers who had the right to allocate $1 \%$ of their income tax was narrowed down. This possibility did not apply to entrepreneurs who paid their tax at so-called flat rate of $19 \%$ or taxpayers of lump sum taxes or the capital gains tax (Piechota, 2015b). In the following years, the number of entities which can subsidise PBOs with $1 \%$ of the tax due was expanded. Nowadays the taxpayers of personal income tax, taxpayers paying a lump sum on recorded revenues, taxpayers who achieve revenues from the sale of real estate, taxpayers of the capital gains tax and taxpayers who pay flat rate tax may assign a part of their tax liability to a $\mathrm{PBO}$.

PBOs are obliged to prepare the annual financial report and the annual performance report as well as to publish these reports after having them approved on the website of the National Freedom Institute (2019) - Centre for Civil Society Development (earlier these reports were published on the website of the minister competent for social security) until July 15 (or 15 days after the approval) (Act on public benefit activities and volunteering, 2003, art. 23).

If an organisation fails to meet this condition, it loses the right to apply for $1 \%$ of tax. The organisation may also lose the public benefit status. The Director of the National Freedom Institute can apply to the registration court to have the information concerning the public benefit status deleted from the National Court Register mainly in the following three situations (Act on public benefit activities and volunteering, 2003, art. 33.2):

- if the organisation failed to remove irregularities defined in post-audit findings;

- if the organisation refused to be the subject of audit;

- if a serious breach of the law is revealed in the course of the audit (as specified in art. 29 of the Act on public benefit activities and volunteering (2003)). 
If the annual performance report or the financial statement are not published in the National Freedom Institute's (2019) database or when these reports are incomplete or raise doubts and the PBO does not respond to the demand of the Director of the National Freedom Institute to remedy the breaches and present relevant clarifications within 30 days of its receipt, the Director of the National Freedom Institute shall request the registration court to delete the information concerning the public benefit status from the National Court Register (Act on public benefit activities and volunteering, 2003, art. 33a.1; Żak, 2012). The legislation indicates eight other situations which may cause the Director of the National Freedom Institute to request to have the public benefit status of an organisation waived. These conditions are connected with failing to perform the duties that are not specific to PBOs but to all organisations, e.g. not obtaining the required permission for conducting public fund-raising or failing to submit information on the settlement of the funds derived from public fund-raising or information on the donations received, etc. (Act on public benefit activities and volunteering, 2003, art. 33a.2 and 33aa).

In case the organisation loses the public benefit status, it can apply to have it restored. If the entity loses the status due to the operations undertaken by the Director of the National Freedom Institute or by the National Court Register, it can reapply to have the public benefit status granted after two years (Act on public benefit activities and volunteering, 2003, art. 22a.1; Żak, 2012).

\section{Materials and methods}

In order to assess the $1 \%$ of personal income tax write-off as a source of revenue for PBOs two sources of information were used. The first one was the statistical information derived from reports prepared by Statistics Poland, while the other were performance reports downloaded from the database available on the website of the National Freedom Institute (2019), where PBOs are obliged to publish their annual financial and performance reports. As indicated above, organisations with the public benefit status have to prepare an annual performance report. Depending on the amount of the revenue, PBOs may prepare a simplified or an unabbreviated annual performance report. Both types contain such data as: the information on the date of obtaining the public benefit status, the scope of public benefit activity conducted, the total amounts of revenues and expenses, and the revenues received from $1 \%$ of personal income tax. Based on the data from the performance reports, the information about total revenue and the revenue from $1 \%$ of tax was collected and analysed. Since the database available on the National Freedom Institute (2019) website encompasses the years 2011-2018, this period was taken under consideration. The information was collected for thirty organisations which obtained the highest amounts from 1\% of personal income tax in 2018.

In order to analyse the data and draw conclusions based on the results, the research methods used for the purpose of writing this paper include a com- 
parative analysis and the methods of descriptive statistics such as arithmetic means and median.

\section{Results}

\subsection{Funds from $1 \%$ of personal income tax: a macro perspective}

Every year Statistics Poland presents the information about the funds from 1\% of income tax obtained by PBOs. According to the latest Statistics Poland (2019) report, PBOs obtained PLN 761 million through the 1\% mechanism in 2018, which is a 15\% increase in funds as compared to PLN 660 million in 2017. At the end of 2017 there were 9.5 thousand PBOs registered in Poland, of which 9.2 thousand were active. PBOs constitute about $10.1 \%$ of all active non-profit organisations, such as: associations and similar social organisations, foundations, religious entities and economic self-governments.

Chart 1 illustrates the total amount of funds obtained from $1 \%$ of personal income tax by PBOs since the introduction of this mechanism in 2004. During the first years after the introduction of the $1 \%$ mechanism there was an intensive growth in donating for PBOs through the tax system. The highest growth had place in 2005 and 2008. The former situation resulted from both the increasing awareness of the newly-introduced mechanism in the society and the information published in mass media. The latter stemmed from a law amendment. Till 2007 the taxpayers who wanted to transfer 1\% of their income tax had to calculate $1 \%$ of the tax due and make a bank transfer to the selected PBO's account. After submitting the tax return, the taxpayers waited for a refund of the amount transferred to the $\mathrm{PBO}$ from the tax authority. This procedure was simplified in 2008. Now the taxpayer has only to indicate the selected PBO, provide its number in the National Court Register and specify in their tax return an amount not exceeding $1 \%$ of the tax due. The declared amount of money will be transferred to selected PBO's bank account by the tax office on behalf of the taxpayer (Misiewicz, 2017, p. 151). In 2010 the contributions transferred decreased due to the impact of the economic crisis and a worse economic situation, which resulted in a lower income of the society and thus smaller amounts of income tax (Czetwertyński, 2016, pp. 73-74). Since 2010 there may be observed a steady increase in the nominal amount of funds obtained by PBOs from the $1 \%$ mechanism. Nevertheless, according to Jegorow (2017, p. 57), the increase in real revenues of PBOs clearly slowed down. She claims that this situation should cause a reflection among the beneficiaries of $1 \%$ that PBOs need to build appropriate relationships with taxpayers willing to make a tax write-off.

Table 1 presents the average and median amounts of $1 \%$ personal income tax which were transferred to PBOs from 2011 to 2018. These statistics were calculated for those organisations which obtained the revenue from 1\% (Statistics Poland, 2019). The average amount from the $1 \%$ mechanism increased by PLN 
26.2 thousand in the analysed period (from PLN 61.5 thousand in 2011 to PLN 87.7 thousand in 2018). Meanwhile, the median decreased by PLN 0.9 thousand (from PLN 5.8 thousand in 2011 to PLN 4.9 thousand in 2018), which indicates a deepening inequality among the organisations. It must be noticed that while the total amount of contributions transferred by taxpayers is increasing, the funds received by a half of the PBOs are decreasing. In the analysed period, the number of PBOs with funds from the $1 \%$ mechanism higher than PLN 1 million did not exceed 0.1 thousand of entities (Statistics Poland, 2019).

The unequal distribution of funds is also confirmed by the data presented in table 2, which contains the information about the number of PBOs obtaining contributions from $1 \%$ of income tax in a specified range and the average amount of money transferred through the $1 \%$ mechanism for this range in 2019. Almost $90 \%$ of all funds transferred were obtained by 683 organisations, which constitute about $8 \%$ of all PBOs that received funds from $1 \%$ of income tax in 2019 . The first six entities gained $36 \%$ of all total funds transferred under the $1 \%$ mechanism. The entities which receive small amounts of $1 \%$ of income tax dominate among the Polish PBOs.

\subsection{Transfers of $1 \%$ of personal income tax: a micro perspective}

Taking into consideration the information presented by PBOs in their annual performance reports, the share of transfers from the $1 \%$ mechanism in total revenues may be examined. The main purpose of this study is to prove the assumption that these funds are the main source of total revenues and an important source of financing the activity of the PBOs receiving the highest amounts under the $1 \%$ mechanism.

Table 3 shows the analysis of $1 \%$ of personal income tax obtained by thirty PBOs with the highest revenue from this source in 2018. Each organisation is described with the information concerning the amount obtained from the $1 \%$ mechanism (row a), total revenue (row b) and the share of transfers from the $1 \%$ mechanism in total revenues (row c). Additionally, the amounts from previous years which are available in the National Freedom Institute (2019) database are presented. Detailed information on the PBOs analysed is provided in table 4.

The results obtained for the organisations analysed in this paper indicate that, in spite of the fact that these entities received the highest amounts from $1 \%$ of income tax, the share of transfers from this source in total revenues varies and equals from $5 \%$ to $100 \%$. In eleven out of thirty PBOs the share of $1 \%$ of income tax did not exceed $50 \%$ of total revenues in any of the years studied. It should also be noticed that the amount obtained from the $1 \%$ mechanism is not a stable source of finance for most of the PBOs analysed. The examination of the situation of individual organisations demonstrates that the share of $1 \%$ of income tax in total revenue varies in the analysed period. Only for three PBOs the difference between the maximum and the minimum share of funds from the $1 \%$ mechanism in total revenues did not exceed 5 percentage points in a given 
period. In the case of two out of thirty PBOs, it is possible to assume that the contributions of $1 \%$ of income tax are a significant and stable source of revenue (1\% transfers determine more than $70 \%$ of revenues each year and this share did not change by more than 6 percentage points during the period analysed).

Every year The Foundation for Children Help on Time (Fundacja Dzieciom Zdażyć z Pomoca) obtains the highest amounts from the 1\% mechanism. In 2018 this amount was almost five times higher than that for the organisation which ranked second. It stems from the fact that this foundation uses sub-accounts for individual beneficiaries - sick and disabled children - which enables taxpayers to transfer $1 \%$ of their tax liabilities not for the general purpose of the organisation, but directly as aid for an individual child. According to the annual performance report, The Foundation for Children Help on Time had 34,786 sub-accounts in 2018. The foundations which obtained the second and the third highest contributions from the 1\% mechanism in 2018 (The Avalon Foundation (Fundacja Avalon) and The Charity Foundation for People with Special Needs Stoneczko (Fundacja Pomocy Osobom Niepełnosprawnym Stoneczko), respectively) also run sub-accounts for individual beneficiaries - sick and disabled adults. The Avalon Foundation had 10,742 of sub-accounts while the Charity Foundation Stoneczko operated 7,793 sub-accounts in 2018. These are three $\mathrm{PBOs}$ with the highest contributions from $1 \%$ of income tax, which accounted for more than $70 \%$ of all revenues in 2018 .

The high popularity of the PBOs that run sub-accounts may be more understandable if we take into consideration a survey concerning the taxpayers' motivation for assigning 1\% of income tax conducted in 2014 by the Klon/Jawor Association. Research results demonstrate that the motives for donating are connected with emotions (people want to help someone they know or someone recommended by relatives, sometimes they also choose the beneficiary spontaneously) (Charycka, 2015). It must be admitted that many PBOs which conduct healthcare-related public benefit activity use the idea of sub-accounts. Despite this, expert literature points out that the introduction of sub-accounts contradicts the idea of the $1 \%$ mechanism aimed at strengthening social economy by providing financial support for public benefit activities because it gives the opportunity to support individuals and to finance non-public purposes (Jegorow, 2017, p. 52; Kietlińska, 2015, pp. 110-111; Piechota, 2015a, pp. 11-12).

Most of the PBOs ran their activity during all the years analysed, so their actions are recognised by taxpayers assigning to them $1 \%$ of their tax due. Nevertheless, four out of the thirty PBOs analysed obtained the public benefit status during the period studied in this paper and, in spite of that, managed to receive a significant amount of $1 \%$ transfers. For example, The Sensoria Foundation (Fundacja Sensoria) obtained the public benefit status in 2017 and received the fourth highest amount from the 1\% mechanism in 2018.

Finally, it is worth mentioning one organisation - The Great Orchestra of Christmas Charity Foundation (Fundacja Wielka Orkiestra Świątecznej Pomocy) - which obtained the sixth highest transfer from $1 \%$ of income tax 
in 2018. The money received from the $1 \%$ mechanism comprises about $5 \%$ of its total revenues, so it is not the main source of financing its activity, but this share is the most stable in the analysed period among the selected thirty entities (the difference between the maximum and the minimum share of the $1 \%$ mechanism in total revenues equals 1.4 percentage points).

\section{Conclusion}

The results of the analysis conducted in this paper indicate that the total amount of funds transferred by taxpayers as well as the average amount obtained from the $1 \%$ mechanism increase every year. These funds seem to be an important source of financing PBOs' activities. However, there is the problem of inequality in distribution of amounts obtained from $1 \%$ of personal income tax. The amounts received by a half of the PBOs are getting lower and almost $90 \%$ of all funds transferred in 2019 were obtained by $8 \%$ of all PBOs that received money from the $1 \%$ mechanism.

The main purpose of this paper is to assess the significance of $1 \%$ of personal income tax for the organisations with the public benefit status that receive the highest amounts in this respect. The PBOs analysed differ in their structure of revenues. The share of funds from $1 \%$ of personal income tax in total revenues equals from $5 \%$ to $100 \%$ in the examined period. In eleven out of thirty PBOs the share of $1 \%$ of income tax did not exceed $50 \%$ of total revenues in any of the years analysed. It can be observed that some PBOs use a special solution in obtaining funds from the $1 \%$ mechanism, based on creating sub-accounts for collecting funds for private beneficiaries. Sixteen out of thirty PBOs analysed use the idea of sub-accounts. They usually conduct healthcare-related public benefit activity. It should be indicated that this solution supports private needs of certain beneficiaries rather, than public benefit activity for the society. Still it is worth noticing that fourteen organisations examined, which do not use the idea of sub-accounts manage to be among the thirty $\mathrm{PBO}$ s that receive the highest amounts from $1 \%$ of personal income tax.

It may be pointed out that $1 \%$ of income tax is an important, but not the main, source of revenue for most of PBOs. Financing PBOs' activity solely or mainly from the funds obtained from the $1 \%$ mechanism increases the risk of conducting the activity because, in general, these funds are not a stable source of finance. It may be observed that the examined period comprises years when the upward trend in the value of PBO's funds from $1 \%$ slows down. Therefore, it should be taken into account that attracting taxpayers willing to transfer $1 \%$ of their income tax to a given $\mathrm{PBO}$ will require not so much seeking taxpayers who have not made this write-off earlier, but reaching individuals who have previously chosen to transfer their $1 \%$ to another organisation. The PBOs for which the $1 \%$ mechanism is the main source of total revenues must take into consideration that these funds may decrease due to the outflow of taxpayers who decide to transfer 1\% to other entities (Jegorow, 2017, p. 60). 
In future research, the scope of the study may be extended by an analysis of the ways and the effectiveness of spending funds obtained from the $1 \%$ mechanism.

\section{References}

Charycka, B. (2015). 1\%: temu dam, kogo znam. Retrieved 10.02.2020 from https://publicystyka.ngo.pl.

Czetwertyński, S. (2016). Konkurencja na rynku jednego procenta. Spoteczeństwo i Ekonomia, 1(5). doi:10.15611/sie.2016.1.05.

Jegorow, D. (2017). Odpis podatkowy „1\%” jako źródło finansowania podmiotów ekonomii społecznej w Polsce: retrospekcja i projekcja poziomu zaangażowania społecznego. Ekonomia Spoteczna, 1. doi:10.15678/ES.2017.1.04.

Kietlińska, K. (2015). Rola 1\% w zasilaniu organizacji pożytku publicznego (OPP). Prace Naukowe Uniwersytetu Ekonomicznego we Wroctawiu, 403. doi:10.15611/pn.2015.403.09.

Ministry of Finance. (2019). Informacja o 1\% podatku PIT przekazanego OPP. Retrieved 07.02.2020 from https://www.gov.pl.

Misiewicz, E.I. (2016). Zmiany przepisów o jednym procencie należnego podatku dochodowego od osób fizycznych a zachowanie podatników. Prace Naukowe Uniwersytetu Ekonomicznego we Wroctawiu, 451. doi:10.15611/ pn.2016.451.24.

Misiewicz, E.I. (2017). Analiza dotowania organizacji pożytku publicznego jednym procentem podatku należnego. Prace Naukowe Uniwersytetu Ekonomicznego we Wroctawiu, 488. doi:10.15611/pn.2017.488.13.

Musiałkiewicz, R. (2014). Udział organizacji pożytku publicznego w podatku dochodowym od osób fizycznych: zagadnienia prawno-finansowe. Prawo Budżetowe Państwa i Samorządu, 1(2). doi:10.12775/PBPS.2014.005.

National Freedom Institute. (2019). Baza sprawozdan finansowych $i$ merytorycznych organizacji pożytku publicznego. Retrieved 28.02.2020 from https:// sprawozdaniaopp.niw.gov.pl.

NIW. (2020). PBO. Retrieved 28.02.2020 from https://www.niw.gov.pl.

Piechota, G. (2015a). Fakty i mity o jednym procencie podatku: odpis podatkowy $w$ procesie kreowania spoteczeństwa obywatelskiego. Warszawa: TAiWPN Universitas.

Piechota, G. (2015b). Legislation on financing public benefit activities from tax designation in Poland. International Journal of Not-for-Profit Law, 17(1).

Statistics Poland. (2019). Organizacje pożytku publicznego i 1\% w latach 2017-2018. Retrieved 10.02.2020 from https://stat.gov.pl.

Ustawa z dnia 24 kwietnia 2003 r. o działalności pożytku publicznego i o wolontariacie [Act of 24 April 2003 on public benefit activities and volunteering] (Dz.U. 2003 nr 96 poz. 873) (Poland).

Ustawa z dnia 25 czerwca 2010 r. o sporcie [Act of 25 June 2010 on sport] (Dz.U. 2010 nr 127 poz. 857) (Poland). 
Ustawa z dnia 6 kwietnia 1984 r. o fundacjach [Act of 6 April 1984 on foundations] (Dz.U. $1984 \mathrm{nr} 21$ poz. 97) (Poland).

Ustawa z dnia 7 kwietnia 1989 r. Prawo o stowarzyszeniach [Act of 7 April 1989 on associations] (Dz.U. $1989 \mathrm{nr} 20$ poz. 104) (Poland).

Żak, P. (2012). Public benefit status in Poland: review of existing legislation. Retrieved 27.06.2016 from http://ofop.eu.

\section{Acknowledgements}

Author contributions: author has given an approval to the final version of the article.

Funding: this research was funded by the Nicolaus Copernicus University in Torun, Faculty of Economic Sciences and Management statutory sources. 


\section{Appendix}

Table 1.

Average and median amounts of 1\% transferred to PBOs in 2011-2018 (in thousand PLN)

\begin{tabular}{rrrrrrrrr}
\hline Data & 2011 & 2012 & 2013 & 2014 & 2015 & 2016 & 2017 & 2018 \\
\hline average & 61.5 & 66.7 & 67.5 & 68.1 & 70.7 & 76.2 & 80.1 & 87.7 \\
median & 5.8 & 5.7 & 5.5 & 5.2 & 5.0 & 5.0 & 4.9 & 4.9 \\
\hline
\end{tabular}

Source: Statistics Poland (2019).

Table 2.

Distribution of contributions from 1\% of personal income tax in 2019

\begin{tabular}{lcc}
\hline Scope of the amount of $1 \%$ (in PLN) & Number of organisations & Average amount of 1\% (in PLN) \\
\hline over $50,000,000$ & 1 & $185,507,307.2$ \\
$(10,000,000-50,000,000>$ & 5 & $25,265,202.4$ \\
$(1,000,000-10,000,000>$ & 107 & $2,864,389.5$ \\
$(100,000-1,000,000>$ & 570 & $280,751.7$ \\
$(10,000-100,000>$ & 2,558 & $30,461.4$ \\
$(1,000-10,000>$ & 4,287 & $4,072.5$ \\
equal or less than 1,000 & 1,341 & 493.9 \\
total & 8,869 & $98,589.8$ \\
\hline
\end{tabular}

Source: Own preparation based on Ministry of Finance (2019).

Table 3.

Analysis of $1 \%$ of personal income tax in thirty PBOs with the highest transfers from this source in 2011-2018

\begin{tabular}{rrrrrrrrrr}
\hline $\begin{array}{c}\text { PBO's } \\
\text { number }\end{array}$ & Data & 2011 & 2012 & 2013 & 2014 & 2015 & 2016 & 2017 & 2018 \\
\hline \multirow{3}{*}{1} & a & 89.5 & 109.3 & 117.7 & 128.0 & 136.8 & 144.5 & 149.4 & 167.1 \\
& b & 119.8 & 141.9 & 149.9 & 165.9 & 178.3 & 184.3 & 194.4 & 224.9 \\
& c & 75.0 & 77.0 & 79.0 & 77.0 & 77.0 & 78.0 & 77.0 & 74.0 \\
2 & a & 1.9 & 4.9 & 8.6 & 11.7 & 15.9 & 21.0 & 27.9 & 37.2 \\
& b & 3.9 & 7.7 & 13.6 & 20.8 & 29.9 & 41.9 & 40.1 & 51.5 \\
& c & 49.0 & 64.0 & 63.0 & 56.0 & 53.0 & 50.0 & 70.0 & 72.0 \\
3 & a & 10.0 & 13.4 & 15.4 & 17.8 & 20.8 & 25.1 & 29.8 & 36.3 \\
& b & 13.2 & 17.4 & 19.5 & 22.8 & 26.8 & 32.5 & 40.6 & 47.7 \\
& c & 76.0 & 77.0 & 79.0 & 78.0 & 78.0 & 77.0 & 73.0 & 76.0 \\
4 & a & - & - & - & - & - & - & - & 13.9 \\
& b & - & - & - & - & - & - & - & 15.3 \\
& c & - & - & - & - & - & - & - & 91.0 \\
& a & - & - & - & 0.1 & 1.2 & 3.9 & 4.8 & 9.7 \\
& b & - & - & - & 0.7 & 8.2 & 21.7 & 27.8 & 48.9 \\
& c & - & - & - & 14.0 & 15.0 & 18.0 & 17.0 & 20.0 \\
\hline
\end{tabular}




\begin{tabular}{|c|c|c|c|c|c|c|c|c|c|}
\hline $\begin{array}{l}\text { PBO's } \\
\text { number }\end{array}$ & Data & 2011 & 2012 & 2013 & 2014 & 2015 & 2016 & 2017 & 2018 \\
\hline \multirow{3}{*}{6} & $\mathrm{a}$ & 3.6 & 3.4 & 3.3 & 3.7 & 3.2 & 4.2 & 7.4 & 8.8 \\
\hline & b & 62.1 & 68.6 & 63.6 & 68.5 & 61.6 & 88.6 & 122.1 & 145.6 \\
\hline & c & 6.0 & 5.0 & 5.0 & 5.0 & 5.0 & 5.0 & 6.0 & 6.0 \\
\hline \multirow{3}{*}{7} & a & 1.6 & 2.8 & 3.5 & 3.8 & 5.2 & 6.4 & 6.7 & 8.2 \\
\hline & $\mathrm{b}$ & 2.2 & 3.9 & 5.4 & 5.4 & 8.0 & 9.9 & 9.6 & 10.8 \\
\hline & $c$ & 73.0 & 72.0 & 65.0 & 70.0 & 65.0 & 65.0 & 70.0 & 76.0 \\
\hline \multirow{3}{*}{8} & a & 5.0 & 6.1 & 6.0 & 6.1 & 6.4 & 7.4 & 7.4 & 8.1 \\
\hline & b & 15.8 & 19.0 & 21.1 & 23.1 & 25.1 & 27.6 & 29.4 & 31.7 \\
\hline & c & 32.0 & 32.0 & 28.0 & 26.0 & 25.0 & 27.0 & 25.0 & 26.0 \\
\hline \multirow{3}{*}{9} & a & 0.2 & 1.7 & 4.8 & 6.1 & 8.3 & 10.1 & 7.7 & 7.9 \\
\hline & $b$ & 0.3 & 1.9 & 5.9 & 9.0 & 14.3 & 10.4 & 8.3 & 8.9 \\
\hline & c & 67.0 & 89.0 & 81.0 & 68.0 & 58.0 & 97.0 & 93.0 & 89.0 \\
\hline \multirow{3}{*}{10} & $\mathrm{a}$ & 2.4 & 2.3 & 2.5 & 3.1 & 4.1 & 5.2 & 5.8 & 7.7 \\
\hline & b & 2.5 & 2.4 & 2.8 & 4.7 & 5.8 & 6.7 & 6.6 & 8.5 \\
\hline & c & 96.0 & 96.0 & 89.0 & 66.0 & 71.0 & 78.0 & 88.0 & 91.0 \\
\hline \multirow{3}{*}{11} & a & 3.9 & 4.7 & 4.4 & 4.9 & 5.2 & 6.0 & 6.8 & 6.7 \\
\hline & b & 7.2 & 8.5 & 7.4 & 7.9 & 10.2 & 12.2 & 13.8 & 16.9 \\
\hline & c & 54.0 & 55.0 & 59.0 & 62.0 & 51.0 & 49.0 & 49.0 & 40.0 \\
\hline \multirow{3}{*}{12} & a & 0.9 & 1.1 & 1.6 & 2.1 & 2.9 & 3.6 & 4.8 & 6.3 \\
\hline & b & 7.2 & 10.1 & 11.3 & 13.0 & 15.2 & 16.8 & 18.4 & 22.4 \\
\hline & c & 13.0 & 11.0 & 14.0 & 16.0 & 19.0 & 21.0 & 26.0 & 28.0 \\
\hline \multirow{3}{*}{13} & a & - & 1.3 & 2.3 & 2.7 & 3.1 & 3.7 & 4.2 & 5.9 \\
\hline & b & - & 1.9 & 3.4 & 3.7 & 4.3 & 5.4 & 6.7 & 9.7 \\
\hline & c & - & 68.0 & 68.0 & 73.0 & 72.0 & 69.0 & 63.0 & 61.0 \\
\hline \multirow{3}{*}{14} & a & 0.7 & 1.7 & 2.3 & 3.0 & 3.8 & 4.5 & 5.0 & 5.8 \\
\hline & b & 0.8 & 2.0 & 2.6 & 3.5 & 4.3 & 5.0 & 5.5 & 6.4 \\
\hline & c & 88.0 & 85.0 & 88.0 & 86.0 & 88.0 & 90.0 & 91.0 & 91.0 \\
\hline \multirow{3}{*}{15} & $\mathrm{a}$ & 2.6 & 2.9 & 3.1 & 3.5 & 4.0 & 4.1 & 4.7 & 5.4 \\
\hline & b & 6.0 & 7.5 & 8.6 & 9.0 & 11.2 & 11.7 & 12.8 & 13.7 \\
\hline & c & 43.0 & 39.0 & 36.0 & 39.0 & 36.0 & 35.0 & 37.0 & 39.0 \\
\hline \multirow{3}{*}{16} & a & 2.9 & 3.7 & 3.6 & 3.5 & 3.6 & 4.4 & 4.4 & 5.2 \\
\hline & b & 15.9 & 17.3 & 18.8 & 19.4 & 20.0 & 22.4 & 21.0 & 24.2 \\
\hline & c & 18.0 & 21.0 & 19.0 & 18.0 & 18.0 & 20.0 & 21.0 & 21.0 \\
\hline \multirow{3}{*}{17} & a & 0.4 & 0.3 & 1.3 & 2.3 & 3.8 & 5.4 & 3.7 & 4.4 \\
\hline & b & 1.4 & 1.3 & 2.9 & 6.3 & 9.8 & 14.8 & 13.7 & 12.3 \\
\hline & c & 29.0 & 23.0 & 45.0 & 37.0 & 39.0 & 36.0 & 27.0 & 36.0 \\
\hline \multirow{3}{*}{18} & a & - & - & - & - & 5.1 & 4.9 & 4.4 & 4.3 \\
\hline & b & - & - & - & - & 10.5 & 8.2 & 6.4 & 6.6 \\
\hline & c & - & - & - & - & 49.0 & 60.0 & 69.0 & 65.0 \\
\hline \multirow{3}{*}{19} & a & 4.1 & 1.4 & 1.5 & 2.0 & 6.9 & 7.3 & 8.6 & 4.3 \\
\hline & b & 4.1 & 4.4 & 4.7 & 5.3 & 6.9 & 7.3 & 9.3 & 4.7 \\
\hline & c & 100.0 & 32.0 & 32.0 & 38.0 & 100.0 & 100.0 & 92.0 & 91.0 \\
\hline \multirow{3}{*}{20} & a & 8.2 & 7.6 & 6.2 & 5.3 & 5.4 & 4.5 & 4.2 & 4.2 \\
\hline & $\mathrm{b}$ & 13.8 & 14.9 & 14.5 & 13.6 & 13.2 & 10.0 & 12.8 & 10.8 \\
\hline & $c$ & 59.0 & 51.0 & 43.0 & 39.0 & 41.0 & 45.0 & 33.0 & 39.0 \\
\hline
\end{tabular}




\begin{tabular}{|c|c|c|c|c|c|c|c|c|c|}
\hline $\begin{array}{l}\text { PBO's } \\
\text { number }\end{array}$ & Data & 2011 & 2012 & 2013 & 2014 & 2015 & 2016 & 2017 & 2018 \\
\hline \multirow{3}{*}{21} & a & 3.5 & 4.5 & 4.7 & 4.5 & 4.2 & 4.0 & 4.0 & 3.9 \\
\hline & $\mathrm{b}$ & 9.2 & 12.5 & 15.6 & 17.5 & 18.5 & 19.4 & 5.4 & 4.9 \\
\hline & $c$ & 38.0 & 36.0 & 30.0 & 26.0 & 23.0 & 21.0 & 74.0 & 80.0 \\
\hline \multirow{3}{*}{22} & $\mathrm{a}$ & 0.9 & 1.5 & 1.9 & 2.1 & 2.2 & 3.1 & 3.8 & 3.8 \\
\hline & $\mathrm{b}$ & 3.0 & 4.6 & 5.8 & 7.0 & 8.1 & 11.7 & 13.2 & 17.9 \\
\hline & c & 30.0 & 33.0 & 33.0 & 30.0 & 27.0 & 26.0 & 29.0 & 21.0 \\
\hline \multirow{3}{*}{23} & $\mathrm{a}$ & 0.8 & 0.6 & 1.4 & 3.7 & 5.3 & 3.3 & 4.0 & 3.7 \\
\hline & $\mathrm{b}$ & 0.9 & 1.5 & 1.8 & 4.1 & 6.3 & 8.2 & 5.6 & 4.7 \\
\hline & c & 89.0 & 40.0 & 78.0 & 90.0 & 84.0 & 40.0 & 71.0 & 79.0 \\
\hline \multirow{3}{*}{24} & a & 0.6 & 0.6 & 1.0 & 1.2 & 1.9 & 1.7 & 3.2 & 3.7 \\
\hline & b & 0.9 & 1.0 & 1.4 & 1.5 & 2.2 & 2.2 & 3.8 & 4.3 \\
\hline & c & 67.0 & 60.0 & 71.0 & 80.0 & 86.0 & 77.0 & 84.0 & 86.0 \\
\hline \multirow{3}{*}{25} & $\mathrm{a}$ & 3.3 & 3.9 & 3.3 & 3.2 & 3.4 & 3.3 & 3.6 & 3.7 \\
\hline & b & 25.6 & 29.3 & 31.8 & 33.8 & 37.4 & 42.5 & 45.7 & 49.6 \\
\hline & c & 13.0 & 13.0 & 10.0 & 9.0 & 9.0 & 8.0 & 8.0 & 7.0 \\
\hline \multirow{3}{*}{26} & a & 0.8 & 1.3 & 1.4 & 1.5 & 2.2 & 2.3 & 2.6 & 3.5 \\
\hline & b & 7.3 & 7.3 & 6.9 & 7.1 & 7.3 & 7.8 & 8.1 & 7.3 \\
\hline & c & 11.0 & 18.0 & 20.0 & 21.0 & 30.0 & 29.0 & 32.0 & 48.0 \\
\hline \multirow{3}{*}{27} & a & 3.6 & 3.6 & 3.4 & 3.6 & 3.8 & 3.6 & 3.9 & 3.5 \\
\hline & b & 10.2 & 9.8 & 10.0 & 10.3 & 12.0 & 12.7 & 12.2 & 11.9 \\
\hline & c & 35.0 & 37.0 & 34.0 & 35.0 & 32.0 & 28.0 & 32.0 & 29.0 \\
\hline \multirow{3}{*}{28} & a & 0.7 & 1.3 & 1.3 & 1.2 & 1.9 & 2.8 & 2.7 & 3.5 \\
\hline & b & 5.2 & 6.4 & 7.2 & 5.5 & 3.7 & 4.8 & 4.4 & 6.3 \\
\hline & c & 13.0 & 20.0 & 18.0 & 22.0 & 51.0 & 58.0 & 61.0 & 56.0 \\
\hline \multirow{3}{*}{29} & a & - & - & - & - & - & - & - & 3.4 \\
\hline & $\mathrm{b}$ & - & - & - & - & - & - & - & 3.4 \\
\hline & c & - & - & - & - & - & - & - & 100.0 \\
\hline \multirow{3}{*}{30} & a & 7.6 & 7.0 & 4.7 & 3.7 & 3.3 & 3.1 & 3.1 & 3.3 \\
\hline & b & 23.2 & 21.7 & 20.0 & 16.7 & 18.7 & 12.5 & 13.6 & 14.4 \\
\hline & $\mathrm{c}$ & 33.0 & 32.0 & 24.0 & 22.0 & 18.0 & 25.0 & 23.0 & 23.0 \\
\hline
\end{tabular}

Notes:

a - amount of $1 \%$ personal income tax (in million PLN);

$\mathrm{b}$ - total revenues (in million PLN);

c - the share of $1 \%$ transfers in total revenues (in \%);

- data is not available or there is a mistake in the report.

Source: Own preparation based on National Freedom Institute (2019). 
Table 4.

\section{Characteristics of thirty PBOs with the highest transfers from 1\% mechanism}

\begin{tabular}{|c|c|c|c|}
\hline $\begin{array}{c}\text { PBO's } \\
\text { number }\end{array}$ & PBO's name & $\begin{array}{l}\text { Year of gaining } \\
\text { PB status }\end{array}$ & Subaccounts \\
\hline 1 & $\begin{array}{l}\text { Fundacja Dzieciom Zdażyć z Pomoca (Foundation for Children Help } \\
\text { on Time) }\end{array}$ & 2004 & yes \\
\hline 2 & $\begin{array}{l}\text { Bezpośrednia Pomoc Niepełnosprawnym Avalon (Direct Assistance for } \\
\text { the Disabled Avalon) }\end{array}$ & 2009 & yes \\
\hline 3 & $\begin{array}{l}\text { Fundacja Pomocy Osobom Niepełnosprawnym Stoneczko (Charity } \\
\text { Foundation for People with Special Needs Stoneczko) }\end{array}$ & 2005 & yes \\
\hline 4 & Fundacja Sensoria (Sensoria Foundation) & 2017 & no \\
\hline 5 & $\begin{array}{l}\text { Fundacja Pomocy Dzieciom i Osobom Chorym Kawatek Nieba (Chil- } \\
\text { dren and Ill People Help Foundation A Piece of Heaven) }\end{array}$ & 2013 & yes \\
\hline 6 & $\begin{array}{l}\text { Fundacja Wielka Orkiestra Światecznej Pomocy (The Great Orchestra } \\
\text { of Christmas Charity Foundation) }\end{array}$ & 2004 & no \\
\hline 7 & $\begin{array}{l}\text { Fundacja Serce Dziecka im. Diny Radziwilłowej (Dina Radziwiltowa } \\
\text { Foundation Child's Heart) }\end{array}$ & 2007 & yes \\
\hline 8 & $\begin{array}{l}\text { Dolnośląska Fundacja Rozwoju Ochrony Zdrowia (Lower Silesia } \\
\text { Foundation for Health Care Development) }\end{array}$ & 2004 & yes \\
\hline 9 & $\begin{array}{l}\text { Fundacja Studencka Mtodzi Mtodym (The Young for the Young Students' } \\
\text { Foundation) }\end{array}$ & 2008 & yes \\
\hline 10 & Fundacja Dzieciom Pomagaj (Foundation for Children Help) & 2007 & yes \\
\hline 11 & $\begin{array}{l}\text { Fundacja Na Ratunek Dzieciom z Chorobą Nowotworowa (Foundation } \\
\text { Helping Children with Cancer Disease) }\end{array}$ & 2004 & no \\
\hline 12 & Fundacja Jim (Jim Foundation) & 2004 & yes \\
\hline 13 & Fundacja Ztotowianka (Ztotowianka Foundation) & 2009 & yes \\
\hline 14 & $\begin{array}{l}\text { Fundacja na rzecz Chorych na Stwardnienie Rozsiane Dobro Powraca } \\
\text { (Foundation for Multiple Sclerosis Patients Good Comes Back) }\end{array}$ & 2009 & yes \\
\hline 15 & $\begin{array}{l}\text { Ogólnopolskie Towarzystwo Ochrony Zwierząt Animals (Animals The } \\
\text { National Association for the Protection of Animals) }\end{array}$ & 2005 & no \\
\hline 16 & $\begin{array}{l}\text { Towarzystwo Opieki nad Zwierzętami w Polsce (Animal Protection } \\
\text { Society in Poland) }\end{array}$ & 2004 & no \\
\hline 17 & $\begin{array}{l}\text { Fundacja Nasze Dzieci przy Klinice Onkologii w Instytucie Pomnik } \\
\text { Centrum Zdrowia Dziecka (Our Children Foundation at The Clinic of On- } \\
\text { cology in The Children's Memorial Health Institute) }\end{array}$ & 2007 & yes \\
\hline 18 & Fundacja Nasza Przysztość (Our Future Foundation) & 2014 & no \\
\hline 19 & $\begin{array}{l}\text { Fundacja Dzieciom z Upośledzeniem Umysłowym Agnieszka (The } \\
\text { Foundation for Children with Mental Retardation Agnieszka) }\end{array}$ & 2007 & no \\
\hline 20 & $\begin{array}{l}\text { Fundacja Anny Dymnej Mimo Wszystko (Anna Dymna’s Foundation } \\
\text { Despite Everything) }\end{array}$ & 2004 & yes \\
\hline 21 & $\begin{array}{l}\text { Polskie Towarzystwo Stwardnienia Rozsianego (Polish Society of Mul- } \\
\text { tiple Sclerosis) }\end{array}$ & 2004 & yes \\
\hline 22 & Fundacja Iskierka (Iskierka Foundation) & 2006 & yes \\
\hline 23 & $\begin{array}{l}\text { Akademia Liderów Innowacji i Przedsiębiorczości Fundacja dr } \\
\text { Bogusława Federa (Academy of Innovation and Entrepreneurship } \\
\text { Leaders dr Bogusław Feder’s Foundation) }\end{array}$ & 2009 & no \\
\hline 24 & $\begin{array}{l}\text { Fundacja na rzecz Pomocy Dzieciom Niepełnosprawnym Nowa Na- } \\
\text { dzieja (New Hope Foundation for Disabled Children) }\end{array}$ & 2009 & yes \\
\hline 25 & $\begin{array}{l}\text { Stowarzyszenie Sos Wioski Dziecięce w Polsce (Sos Children's Villages } \\
\text { in Poland Association) }\end{array}$ & 2004 & no \\
\hline 26 & Fundacja Dr Clown (Dr Clown Foundation) & 2004 & no \\
\hline 27 & $\begin{array}{l}\text { Fundacja Warszawskie Hospicjum dla Dzieci (The Warsaw Hospice for } \\
\text { Children Foundation) }\end{array}$ & 2004 & no \\
\hline
\end{tabular}




\begin{tabular}{llcc}
\hline $\begin{array}{c}\text { PBO's } \\
\text { number }\end{array}$ & \multicolumn{1}{c}{ PBO's name } & $\begin{array}{c}\text { Year of gaining } \\
\text { PB status }\end{array}$ & Subaccounts \\
\hline 28 & Chrześcijańska Stużba Charytatywna (Christian Charity Service) & 2004 & no \\
29 & Fundacja Ander (Ander Foundation) & 2014 & no \\
30 & Fundacja TVN Nie Jesteś Sam (TVN You Are Not Alone Foundation) & 2004 & no \\
\hline
\end{tabular}

Source: Own preparation based on National Freedom Institute (2019).

Chart 1.

Total funds transferred to PBOs under the 1\% mechanism in 2004-2018 (in million PLN)

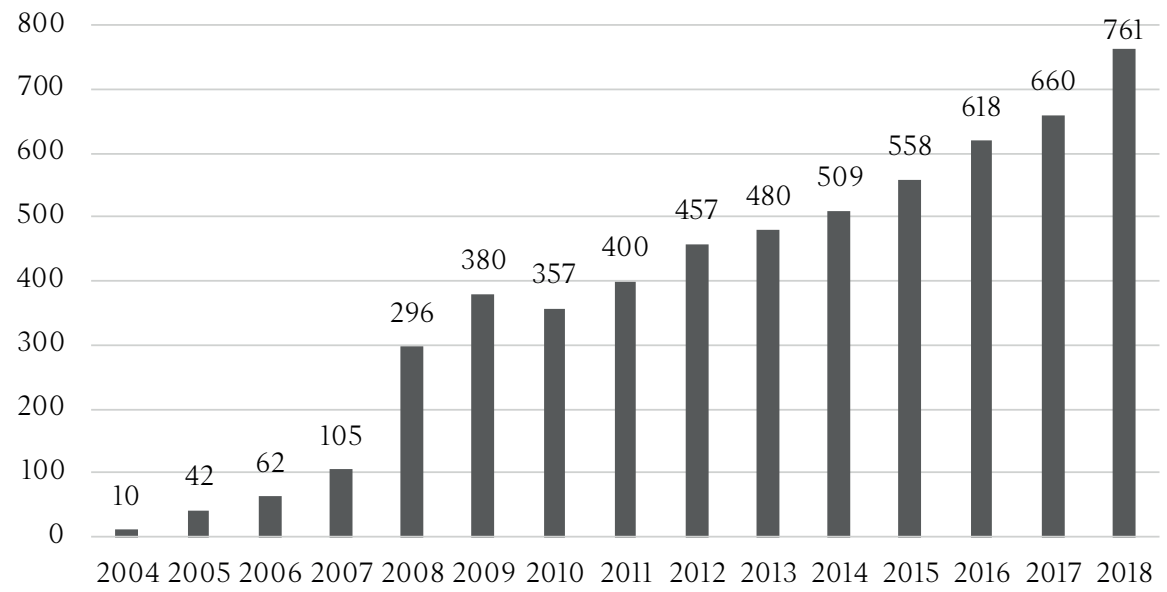

Source: Statistics Poland (2019). 
